\title{
LOST YEARS OF POTENTIAL LIFE IN THE POPULATION OF UKRAINE AS AN INDICATOR FOR THE DETERMINATION OF HEALTH CARE PRIORITY TASKS
}

\section{Serdiuk A.M., Kartashova S.S. ВТРАЧЕН РОКИ ПОТЕНЦІЙНОГО ЖИТТЯ СЕРЕД НАСЕЛЕННЯ УКРАЇНИ
ЯК ПНДИКАТОР ВИЗНАЧЕННЯ ПРІОРИТЕТНИХ ЗАВДАНЬ ОХОРОНИ ЗДОРОВ’Я}

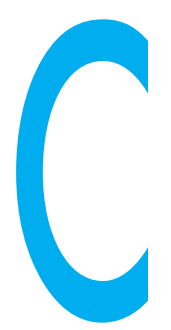

1СЕРДЮК А.М., 2КАРТАШОВА C.C.

1ДУ «Інститут громадського здоров'я ім. О.М. Марзєєва

НАМН України», м. Київ

2Київський національний торговельно-економічний університет, м. Київ

Ключові слова: втрачені роки потенційного життя, стандартизований ризик передчасної смертності за причинами смерті, недоотримана та потенційна вигода. оціально-економічне благополуччя нашої держави, як і будьякої іншої, значною мірою залежить від стану здоров'я їі населення [1].

Низька народжуваність, висока смертність, особливо передчасна, від'ємне сальдо міграції, що спостерігалися в Україні протягом останнього десятиріччя, призвели передусім до зниження чисельності постійного населення переважно працездатного віку та молодшого. Це негативно вплинуло на перебіг основних процесів відтворення, поглибило демографічну кризу, відбилося на погіршенні добробуту населення.

Лише за 2015-2017 роки, без урахування тимчасово окупованих територій України Донецької та Луганської облас тей, чисельність постійного населення віком до 70 років скоротилася на 156,2 тис. осіб і станом на 01.01.2018 р. становила 32135 тис. осіб [2].

Відомо, що подолання соціально-демографічної кризи у державі має здійснюватися не лише за рахунок підвищення народжуваності, а й шляхом зниження смертності, насамперед передчасної, зростання тривалості життя її працездатного населення.

Останнє зумовлене тим, що передчасна смертність $€$ досить чутливим індикатором не тільки соціально-економічних умов життя населення, а й стану державної системи охорони здоров'я загалом.

Результативна оцінка наслідків застосування новітніх технологій у галузі охорони здоров'я $\epsilon$ ефективним механізмом прийняття управлінських
ПОТЕРЯННЫЕ ГОДЫ ПОТЕНЦИАЛЬНОЙ ЖИЗНИ СРЕДИ НАСЕЛЕНИЯ УКРАИНЫ КАК ИНДИКАТОР ОПРЕДЕЛЕНИЯ ПРИОРИТЕТНЫХ ЗАДАЧ ЗДРАВООХРАНЕНИЯ

1 Сердюк А.М., 2 Карташова С.С.

1 ГУ «Институт общественного здоровья им. А.Н. Марзеева НАМН Украины», Г. Киев

${ }^{2}$ Киевский национальный торгово-экономический университет, г. Киев

Цель исследования заключалась в совершенствовании и применении методики оценки здоровья населения Украины по показателю ПЛПЖ в медико-демографическом и финансово-экономическом аспектах, ранжированию областей Украины по стандартизированному риску преждевременной смертности.

Материалы и методы. В качестве источников первичной информации использованы данные о поло-возрастной структуре населения и форм государственной статистической отчетности. Результаты. Среднегодовой объем потерянных лет потенциальной жизни по всем причинам смерти (АОО-Ү99) среди населения Украины в течение 2015-2016 годов составил 3098840 чел.-лет, в том числе по трем лидирующим классам причин смерти: 909848 чел. -лет - от болезней системы кровообращения, 523139 чел. -лет - от новообразований, 670169 чел. -лет - по внешним причинам.

Результаты ранжирования областей государства по стандартизированному отношению ПлПЖ свидетельствуют, что наихудшая ситуация с потерями от преждевременной смертности (все причины смерти) сложилась в Днепропетровской и Житомирской областях, наилучшая - в Винницкой, Тернопольской и Ивано-Франковской, где максимальное значение относительного риска по сравнению с другими территориями государства на 5\% уровне значимости не превышает 0,8.

Упущенная выгода государства за 2015-2016 годы вследствие преждевременной смертности населения (все причины смерти) в денежном эквиваленте составила 433838 млн. грн., при этом суммарный удельный вес трех основных классов причин смерти (I00-199, C00-D48, V01Y99) не превышает 68\%, хотя в классической структуре смертности он приблизительно равен $87 \%$. Последнее свидетельствует о том, что должное внимание не уделяется преждевременной смертности по таким причинам, как инфекционные и паразитарные болезни (A00-B99), болезни органов дыхания (J00-J99) и органов пищеварения (КОО-К93), отдельным состояниям, возникающим в перинатальном периоде (Р00P96), врожденным порокам развития, деформациям и хромосомным аномалиям (Q00-Q99). Ключевые слова: потерянные годы потенциальной жизни, стандартизированный риск смертности по причинам смерти, упущенная и потенциальная выгода.

๔) Сердюк А.М., Карташова С.С. СТАТТЯ, 2019. 
рішень, що базується на засадах доказової медицини та забезпечує оптимізацію витрат за раціонального використання бюджетних коштів [3]. Окремо зазначимо, що збільшення та розподіл інвестицій в охорону громадського здоров'я вимагає надійного обґрунтування як пріоритетних напрямків і заходів державної політики, так і оцінки соціально-економічного ефекту від їх реалізації.

Показник втрачених років потенційного життя (ВРПЖ, англ. Potential Years of Life Lost PYLL) є одним із сучасних засобів, що використовуються для інтегральної оцінки втрат здоров'я населення [4]. Він $\epsilon$ одним 3 індикаторів добробуту населення, яким користуються Світовий банк, Організація економічного співробітництва і розвитку (ОЕСР), Всесвітня організація охорони здоров'я (ВООЗ), Євросоюз [5].

На відміну від традиційних індикаторів громадського здоров'я, зокрема показників смертності, ВРПж акумулює два аспекти втрат: по-перше, абсолютне число померлих, по-друге, вік, в якому настала смерть. Це дозволяє оцінити внесок померлих певного віку у загальну структуру смертності, виявити основні причини передчасної смертності, ефективність системи загальнопопуляційної профілактики та охорони здоров'я. При цьому треба розуміти, що втрати через смерть однієї особи віком 40 років та десяти осіб віком 67 років еквівалентні при дослідженні населення віком до 70 років. Останнє є особливо важливим для адекватної оцінки значущості втрат, зумовлених причинами, можливо, не наймасовішими, але притаманними працездатним літнім та молодшим групам і належать до категорії причин смерті, яким можна запобігти. Більш того, за наявності грошової оцінки вартості одного людино-року абсолютне значення ВРПЖ дозволяє оцінювати ці медико-демографічні втрати у фінансово-економічному еквіваленті. Тобто його доцільно використовувати для оцінки соціально-економічного стану окремої країни, а через відповідну стандартизацію також проводити коректні регіо-

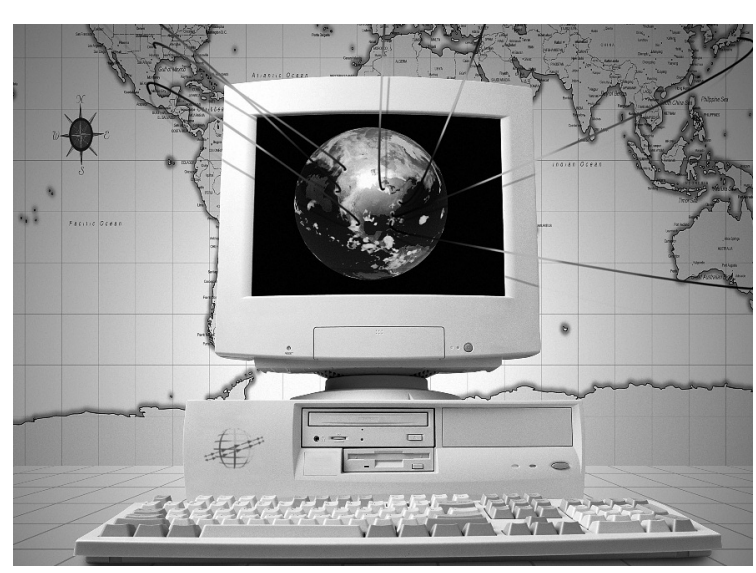

ФУНДАМЕНТАЛЬНІ ДОСЛІДЖЕННЯ

нальні чи міжнародні співставлення (порівняння).

На жаль, в Україні показник втрачених років потенційного життя ще не отримав належного поширення при інтегральній оцінці громадського здоров'я незважаючи на його суттєві переваги: для розрахунку оцінки ВРПЖ існує й інформаційна база, й відповідна методика обчислення, зокрема удосконалена у поточному дослідженні.

Таким чином, мета поточного дослідження полягала в удосконаленні та застосуванні існуючої методики оцінки втрат здоров'я населення держави за показником ВРПЖ у медикодемографічному (абсолютне число втрачених людино-років за причинами смерті) та у фінансово-економічному аспектах (недоотримана та потенційна вигода), ранжуванні областей України за стандартизованим відносним ризиком передчасної смертності.

Матеріали та методи. Як інформаційну базу використано демографічні щорічники, дані статево-вікової структури постійного населення та експрес-випусків Державної служби статистики України, форми державної статистичної звітності, а саме: ф. С-8 «Розподіл померлих за статтю, віковими групами і причинами смерті», Ф. А-1 «Загальні підсумки природного руху» за 2012-2016 роки [6].

Враховуючи політичну ситуацію в Україні, що склалася, 3 2014 року із статистичних державних даних було виключено відомості про населення тимчасово окупованих АРК, міста Севастополь, Донецької та Луганської областей. Це дозволило провести не тільки коректний аналіз порівнянь та співставлень щодо стану громадського здоров'я, а й досто- вірно оцінити тенденції змін у державі за увесь п'ятирічний період спостереження (20122016).

При виконанні поточного дослідження 3 використанням сучасних інформаційних технологій застосовано системний підхід, що базується на поєднанні методів соціально-економічної статистики, медикодемографічних, актуарної математики, теорії ймовірностей та математичної статистики.

Результати та їх обговорення. Державна статистична звітність про захворюваність та смертність населення від 2005 року подається згідно 3 Міжнародною класифікацією хвороб десятого перегляду (MKX-X). Це дозволяє проводити коректні співставлення та порівняння стандартизованих показників смертності за класами хвороб і за окремими нозологіями на міжнародному рівні. Дійсно, статистику смертності різних країн можна вважати найбільш співставною незважаючи на суттєві розбіжності у практиці реєстрації та класифікації причин смерті. Останне зумовлене тим, що надійність інформації за причинами смерті залежить від відомостей, на підставі яких лікар виписує свідоцтво про смерть, а також від правильності класифікації основної причини смерті та від практики кодування.

Структура причин смертності в Україні за класичним визначенням цілком стабільна. Так, протягом 2015-2016 років перші шість рангових місць без урахування симптомів, ознак та відхилень від норми, що виявлені клінічними і лабораторними дослідженнями (не класифіковані в інших рубриках), за MKX-X посідають хвороби системи кровообігу (IO0199: 67,8\%), новоутворення (C00-D48: 13,6\%), зовнішні 
причини смерті (V01-Y99: 5,7\%), хвороби органів травлення (К00-К93: 3,8\%), дихання (J00-J99: 2,4\%), деякі інфекційні та паразитарні хвороби (А00-В99: 1,6\%). При цьому середній вік померлих за цими класами причин суттєво різний і становить $76,65,48,58,64$ та 45 років відповідно.

Для виявлення значущості та обсягу соціально-демографічних втрат, передусім за рахунок передчасної смертності (до 70 років), доцільно під час побудови їхніх інтегральних оцінок враховувати вікову структуру померлих стратифіковано за статтю.

Саме абсолютний показник ВРПЖ (PYLL) оцінює кількість років, не дожитих популяцією до деякого нормативного віку, який у даному дослідженні прийнято за 70 років. Припускаємо, що кожен індивідуум має 70 років «продуктивного» життя, тому смерть у віці $X$ років призводить до втрати $L=(70-X)$ років життя (за $Х<70)$.

Враховуючи те, що дані про смерть на рівні Національної служби статистики України переважно агреговані за п'ятирічними віковими інтервалами, вважається, що момент смерті має рівномірний розподіл на відповідному віковому інтервалі.

Таким чином, $P Y L L=\sum_{\text {в усіх віко- }}$ вих групах до 70 років $\left.D_{i} L_{i}\right)$, де $D_{i}-$ число померлих в $i$-й віковій групі, $L_{i}=70-X_{i}$, а $X_{i}$ - середина $i-$ го вікового інтервалу.
Структуру смертності в Україні для найбільш вагомих класів причин смерті за абсолютним показником ВРПЖ та класична протягом 2015-2016 років наведено у таблиці 1 , стратифіковано за статтю.

Окремо зазначимо, що основну частку в останній рядок цієї таблиці «інші причини смерті» внесли хвороби нервової системи і розлади психіки серед чоловічого населення (у загальній структурі ВРПЖ - 2,9\%) та ендокринні хвороби і хвороби нервової системи у жіночого населення (відповідно 4,1\%).

Порівнюючи класичну структуру смертності та за ВРПж (дисперсійний аналіз за однією ознакою), слід зазначити їхню суттєву різницю менше ніж на $1 \%$ рівня значущості.

Хоча перші три рангові місця за показником втрачених років для чоловічого населення посідають ХСК, зовнішні причини, новоутворення, а для жіночого - ХСК, новоутворення, зовнішні причини, але порівняно 3 класичною структурою внесок ХCK у загальні втрати через передчасну смертність скоротився більш ніж втричі серед жіночого населення та близько двох разів - у чоловічого.

При цьому збільшилася питома вага зовнішніх причин (у 2,8 разів для чоловіків та у 5,5 для жінок), інфекційних хвороб, окремих станів перинатального періоду та вроджених вад розвитку.
Додатково зауважимо, що при зміні профілю розгляду нозологій, пов'язаних прямо або опосередковано зі зловживанням алкоголю, тобто наприклад, приєднавши до зовнішніх причин смерті алкогольну кардіоміопатію (142.6), алкогольну хворобу печінки (К70), хронічний панкреатит алкогольної етіології (К86.0), при цьому вилучивши їх відповідно із ХСК та хвороб органів травлення, то на перше рангове місце вийдуть зовнішні причини смерті у чоловіків і новоутворення у жінок, що й визначає провідні індикатори передчасної смерті залежно від статі.

Загальний обсяг втрачених років потенційного життя в Україні у середньому за 20152016 роки становив 3098840 людино-років, а за окремими класами причин смерті наведено у таблиці 2.

Як свідчать раніш проведені дослідження [7], економічний еквівалент вартості середньостатистичного життя в Україні протягом 2015-2016 років

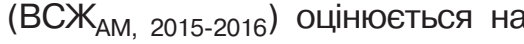
рівні 2,1 млн. грн. Звідси випливає, що середньозважена за обліковою ставкою НБУ (ставка рефінансування) вартість одного людино-року у цей період, згідно з методами актуарної математики, в економічному еквіваленті становила протягом останніх двох років близько 70 тис. грн., як 1/30 вартості середньостатистичного життя людини.

Таблиця 1

Питома вага у класичній структурі та за ВРПЖ окремих класів причин смерті, Україна, 2015-2016 роки

\begin{tabular}{|c|c|c|c|c|}
\hline \multirow{3}{*}{ Клас причин смерті (МКХ-X) } & \multicolumn{4}{|c|}{ Стать } \\
\hline & \multicolumn{2}{|c|}{ чоловіки } & \multicolumn{2}{|c|}{ жінки } \\
\hline & класична & за ВРПЖ & класична & за ВРПЖ \\
\hline І. Деякі інфекційні та паразитарні хвороби (А00-В99) & 2,40 & 7,00 & 0,88 & 6,89 \\
\hline II. Новоутворення (C00-D48) & 15,50 & 13,39 & 11,68 & 25,30 \\
\hline IX. Хвороби системи кровообігу (I00-I99) & 59,94 & 30,50 & 75,26 & 26,61 \\
\hline Х. Хвороби органів дихання (J00-J99) & 3,43 & 4,20 & 1,37 & 3,42 \\
\hline XI. Хвороби органів травлення (К00-К93) & 4,69 & 8,51 & 2,81 & 9,17 \\
\hline $\begin{array}{l}\text { XVI. Окремі стани, що виникають у перинатальному періоді } \\
\text { (P00-P96) }\end{array}$ & 0,33 & 2,68 & 0,24 & 4,94 \\
\hline $\begin{array}{l}\text { XVII. Вроджені вади розвитку, деформації та } \\
\text { хромосомні аномалії (Q00-Q99) }\end{array}$ & 0,29 & 1,94 & 0,21 & 3,36 \\
\hline XVIII. Симптоми, ознаки та відхилення від норми (R00-R99) & 2,02 & 2,04 & 3,38 & 1,14 \\
\hline XX. Зовнішні причини (V01-Y99) & 9,17 & 25,38 & 2,29 & 12,57 \\
\hline Усі інші причини смерті & 2,23 & 4,36 & 1,88 & 6,60 \\
\hline
\end{tabular}


LOST YEARS OF POTENTIAL LIFE

IN THE POPULATION OF UKRAINE

AS AN INDICATOR FOR THE DETERMINATION

OF HEALTH CARE PRIORITY TASKS

1 Serdiuk A.M., 2 Kartashova S.S.

1 SI «O.M. Marzieiev Institute for Public Health, National Academy of Medical Sciences

of Ukraine», Kyiv, Ukraine

2 Kyiv National University of Trade and Economics,

$\underline{\text { Kyiv, Ukraine }}$

Objective: We improved the application of the methodology for the evaluation of the health of the population of Ukraine in terms of PLYPL in medicodemographic and financial-and-economic aspects, ranking of the regions of Ukraine by the standardized parameter of premature death risk.

Materials and methods: The data on gender and age structure of the population and the forms of state statistical reporting were used as a source of primary information.

Results and conclusions: In the population of Ukraine, the average annual number of the lost years of potential life of all causes of death (AOOY99) amounted to 3098840 person-years during 2015-2016, in particular, by three leading classes of the causes of death, these losses made up 909848 person-years of the disease of circulatory system, 523139 person-years of tumors, 670169 person-years of external causes.

The results of the ranking of the regions of the state by the standardized attitude of PLYPL indicated that the worst situation with the losses from premature mortality (all causes of death) was in

Dnipropetrovsk and Zhytomyr regions, the best - in Vinnytsia, Ternopil, and Ivano-Frankivsk regions where the maximum relative risk in comparison with the other state territories did not exceed $0.8 \%$ at $5 \%$ significance level.

The lost profit of the state for 2015-2016 as a result of premature mortality of the population (all causes of death) in monetary terms made up 433838 millions $U A H$, while the total contribution of three main classes of causes of death (I00-199, C00-D48, V01Y99) didn't exceed 68\%, although in the classical structure of mortality, it is approximately equal $87 \%$. The latter indicates that a proper attention isn't paid to premature mortality due to such reasons as infectious and parasitic diseases (AOOB99), respiratory diseases (J00-J99) and diseases of digestive organs (K00-K93), certain states, arising in the perinatal period (P00-P96), congenital malformations, deformities and chromosomal abnormalities (Q00-Q99).

\section{Keywords: lost years of potential life, standardized risk of mortality by causes of death, lost and potential profit.}

Враховуючи це, можна констатувати, що середньорічна упущена вигода держави у вартісному еквіваленті становила 216919 млн. грн., а за окремими класами причин смерті подана у таблиці 2.

При цьому втрати серед чоловічого населення у 2,4 рази вищі, ніж у жіночого. Це поясню-

ється саме надсмертністю чоловіків працездатного віку та молодших, а не зумовлене їхньою суто біологічною різницею.

Абсолютний показник ВРПЖ доцільно використовувати при розв'язанні таких задач, як характеристика масштабу втрат, оцінка структури втрат за причинами смерті (класи, нозоло- гії), оцінка демографічних втрат в економічному еквіваленті, але не підходить для регіональних порівнянь та міжнародних співставлень.

Відносний коефіцієнт ВРПЖ розраховується як PYLL (чисельність постійного населення віком до 70 років). Він дозволяє досліджувати динаміку

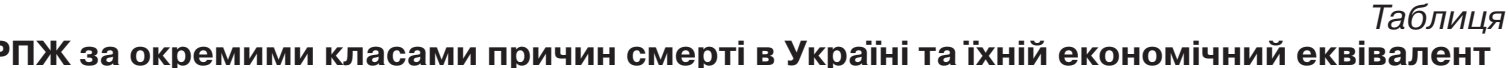
(вартість) у середньому за 2015-2016 роки

\begin{tabular}{|c|c|c|c|c|}
\hline \multirow{3}{*}{ Клас причин смерті (MКX-X) } & \multicolumn{4}{|c|}{ Стать } \\
\hline & \multicolumn{2}{|c|}{ чоловіки } & \multicolumn{2}{|c|}{ жінки } \\
\hline & $\begin{array}{l}\text { ВРПЖ, } \\
\text { люд. - роки }\end{array}$ & $\begin{array}{l}\text { вартість } \\
\text { млн. грн. }\end{array}$ & $\begin{array}{l}\text { ВРПЖ, } \\
\text { люд. - роки }\end{array}$ & $\begin{array}{l}\text { вартість } \\
\text { млн. грн }\end{array}$ \\
\hline Усі причини смерті (А00-Ү99) & 2190832 & 153358 & 908008 & 63561 \\
\hline І. Деякі інфекційні та паразитарні хвороби (А00-В99) & 153363 & 10735 & 62560 & 4379 \\
\hline II. Новоутворення (C00-D48) & 293416 & 20539 & 229723 & 16081 \\
\hline IX. Хвороби системи кровообігу (I00-I99) & 668209 & 46775 & 241639 & 16915 \\
\hline Х. Хвороби органів дихання (J00-J99) & 92014 & 6441 & 31090 & 2176 \\
\hline XI. Хвороби органів травлення (К00-К93) & 186414 & 13049 & 83226 & 5826 \\
\hline $\begin{array}{l}\text { XVI. Окремі стани, що виникають у перинатальному } \\
\text { періоді (P00-P96) }\end{array}$ & 58808 & 4117 & 44868 & 3141 \\
\hline $\begin{array}{l}\text { XVII. Вроджені вади розвитку, деформації } \\
\text { та хромосомні аномалії (Q00-Q99) }\end{array}$ & 42557 & 2979 & 30505 & 2135 \\
\hline $\begin{array}{l}\text { XVIII. Симптоми, ознаки та відхилення від норми } \\
\text { (R00-R99) }\end{array}$ & 44665 & 3127 & 10312 & 722 \\
\hline XX. Зовнішні причини (V01-Y99) & 556064 & 38925 & 114105 & 7987 \\
\hline Усі інші причини смерті & 2190832 & 153358 & 908008 & 63561 \\
\hline
\end{tabular}


показника, виявляти його значущі тенденції змін та будувати попередній (експертний) прогноз.

Для порівняння та співставлень популяцій з суттєво різрою за показником ВРПЖ рекомендується проводити стратифікацію (за статтю) та стандартизацію (за віком).

Стандартизація прямим методом здійснюється за допомогою вибору відповідного стандарту (у поточному дослідженні - європейська стандартна популяція) та визначає, яким був би коефіцієнт втрачених років потенційного життя, якби вікова структура популяції, що вивчається, була такою ж, як у стандарті.

Стандартизований за віком коефіцієнт ВРПЖ $\left(P S_{P Y L}\right)$ оцінюється як

$$
P S_{P Y L L}=\sum_{i} * \frac{D_{i}}{N_{i}} * \frac{N_{S i}}{N_{S T}},
$$
ною статево-віковою структу-

де $N_{i}$ - чисельність популяції, що вивчається у віковій групі $i$, $N_{s i}$ - відповідна чисельність стандартної популяції, $N_{S T}-$ чисельність стандартної популяції до 70 років. Середньоквадратична похибка (s.e. $\left.P S_{P Y L L}\right)$ обчислюється за суперпозицією рівномірного та біноміального розподілів, як це зроблено у роботі [8], і дозволяє виявляти значущі зміни на прийнятому рівні значущості.

Динаміку стандартизованого показника смертності та стандартизованого показника ВРПЖ через усі причини смерті окремо для жіночого та чоловічого населення держави наведено на рисунку 1.

Тоді як показник смертності має значущу тенденцію до зростання, показник ВРПЖ демонструє тенденцію до зменшення, з локальним піком (на 5\% рівні значущості) 2014 року на рівні 49,38\%о і $128,84 \%$ в відпо-

Рисунок 1

\section{Динаміка стандартизованого рівня смертності через усі причини смерті (MKX-X: A00-Y99) за 2012-2016 роки, Україна, \%о}

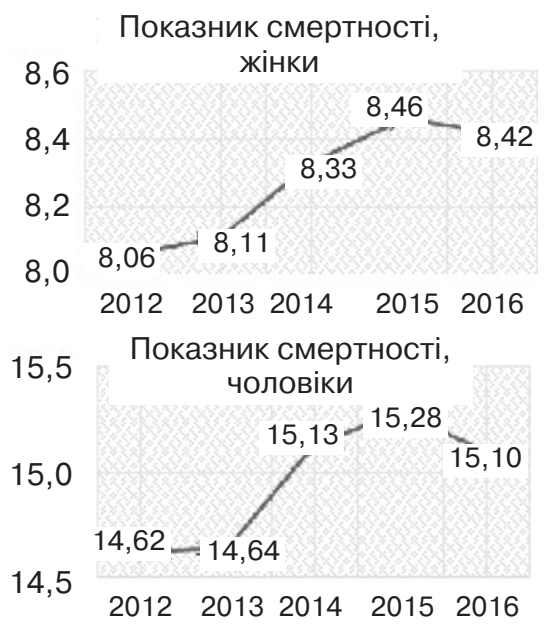

Показник ВРПЖ, жінки
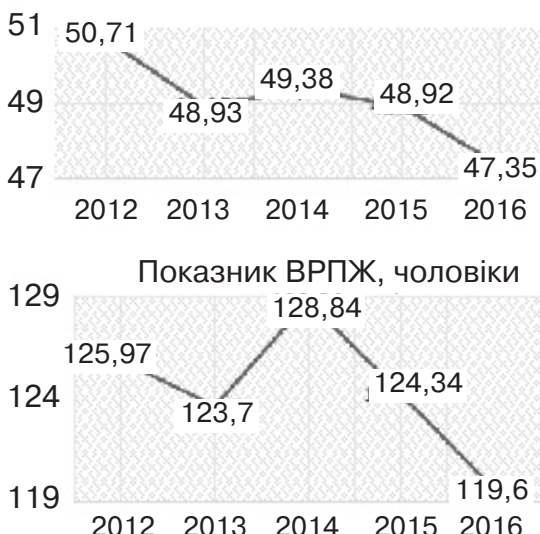

відно для жінок та чоловіків. Більш детальний аналіз виявив, що останне в основному обумовлено збільшенням втрат від XCK та зовнішніх причин смерті, можливо, також і внаслідок політичної ситуації в Україні.

Для ранжування територій за ВРПж застосовано відповідний показник, який стандартизований за непрямим методом, тобто стандартизоване співвідношення (RR), що розраховується як співвідношення дійсного числа втрачених років потенційної життя (PYLL) та очікуваного $\left(P Y L L_{e}\right)$, $R_{P Y L L}=\frac{P Y L L}{P Y L} \quad \begin{aligned} & \text { де } \sum_{i} D_{e i} L_{i}, D_{e i}=N_{i} \cdot M_{s i}, \\ & M_{s i}-\text { коефіцієнт }\end{aligned}$ PYLL смертності в $i$-й віковій групі стандарту, $N_{i}$ - відповідна чисельність досліджуваного населення. Точність стандартизованого співвідношення (s.e. $R_{P Y L L}$ ) обчислюється як s.e. $\left(R_{P Y L L}\right)=1 / \sqrt{P Y L L_{e}}$.

Застосування методу непрямої стандартизації [9] дозволило проранжувати області держави за показником ВРПж через усі причини смерті і за окремими класами причин для жіночого та чоловічого населення (рис. 2).

Найбільших втрат протягом 2016 року зазнало жіноче населення Дніпропетровської області порівняно з іншими територіями держави, де рівень втрат перевищив очікуваний майже на 29\% (RR=1,29; 95\% ДІ: 1,281,30), Кіровоградської - на 24\% (RR=1,24; 95\%ДІ: 1,231,26), Житомирської - на 19\% (RR=1,19; 95\%ДІ: 1,18-1,20).

Перше рангове місце за втратами через передчасну смерть (порівняно 3 іншими

Рисунок 2

Результати ранжування областей держави за стандартизованим співвідношенням ВРПЖ, усі причини смерті (МКX-X: АО0-Y99), 2016 р.
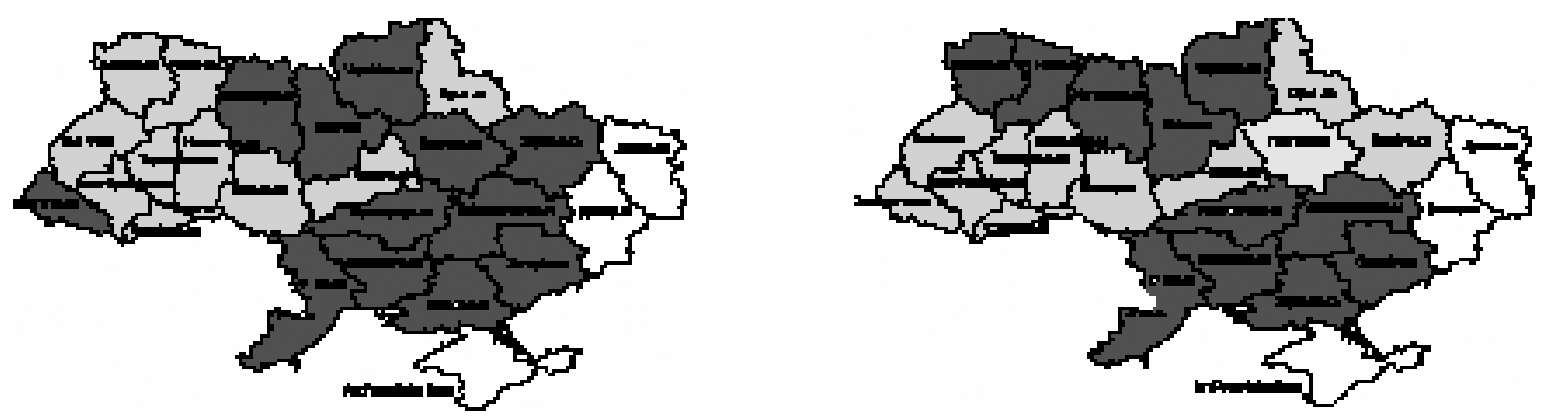

Ризик нижчий, ніж по іншим територіям країни.

Відносний ризик статистично не відрізняється від одиниці.

Ризик вищий, ніж по іншим територіям країни. 
територіями України) виявлено серед чоловічого населення Житомирської (RR=1,23), Чернігівської (RR=1,21) та Дніпропетровської $(\mathrm{RR}=1,19)$ областей.

Значно менше, ніж очікувалося, виявлено втрат потенційних років життя серед населення Вінницької, Тернопільської та Івано-Франківської областей, де максимальне значення відносного ризику не перевищує 0,77 на 5\% рівні значущості.

Аналогічне дослідження було проведене у розрізі таких класів причин смерті, як зовнішні причини, хвороби системи кровообігу, новоутворення, інфекційні та паразитарні хвороби.

Як свідчать результати проведеного ранжування областей України за втратами від зовнішніх причин смерті, 2016 року найнебезпечніша ситуація склалася серед жіночого населення Кіровоградської $(\mathrm{RR}=1,49)$ та чоловічого населення Житомирської $(R R=1,40)$ областей, а найліпша - по місту Київ ( $R R=0,59$, жінки) та у Вінницькій області (RR=0,18 -чоловіки).

У таблиці 3 наведено інтервальні оцінки стандартизованого співвідношення ВРПЖ

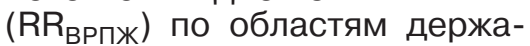
ви, що посідають три перші та три останні місця у рейтингу втрат через передчасну смертність за рахунок зовнішніх причин.

Щодо втрат від ХСК, то найнебезпечніша ситуація 2016 року склалася серед населення Житомирської ( $\mathrm{RR}=1,3$-, жінки; $\mathrm{RR}=1,28$ - чоловіки) та Київської $(\mathrm{RR}=1,20$ - жінки; $\mathrm{RR}=1,26$ - чоловіки) областей, а найліпша - у Тернопільській, Львівській (RR=0,64 - жінки; $\mathrm{RR}=0,68$ - чоловіки) та Вінницькій областях.

Перевищення очікуваного рівня втрат через новоутворення виявлене серед жіночого населення Кіровоградської $(R R=1,20)$, Дніпропетровської та Одеської (RR=1,16) областей, а серед чоловічого населення - Київської $(R R=1,14)$, Житомирської $(\mathrm{RR}=1,11)$ та Закарпатської $(R R=1,09)$. Найбільш благополучні за зниженим ризиком онкологічних втрат західні області держави (ІваноФранківська, Тернопільська) та м. Київ (зокрема, $\mathrm{RR}=0,75$ для чоловічого населення).

Підвищений рівень небезпеки від втрат через інфекційні та паразитарні хвороби: Дніпропетровська $(\mathrm{RR}=3,21$ - жінки; $\mathrm{RR}=2,54$ - чоловіки), Одеська $(\mathrm{RR}=2,37$ - жінки; $\mathrm{RR}=1,75$ чоловіки), Миколаївська $(\mathrm{RR}=$ 1,90 - жінки), Кіровоградська $(\mathrm{RR}=1,50$ - чоловіки) області, найнижчий - серед населення Тернопільської (RR=0,18 - жінки) та Вінницької $(\mathrm{RR}=0,13$ - чоловіки) областей.

Виявлене значення надлишкових ВРПЖ у населення окремих областей України дозволяє оцінити у грошовому вимірі потенційну вигоду та ефективність заходів, насамперед системи охорони здоров'я, спрямованих на зниження передчасної причинно-специфічної смертності хоча б до середньодержавного рівня.

Так у таблиці 4 наведено приклад оцінки потенційної вигоди держави від зниження $\mathrm{RR}_{\text {Врпж }}$ серед населення областей підвищеного ризику до рівня, який не перевищує одиницю на 5\% рівні значущості.

Як свідчать результати проведених розрахунків (табл. 4), якщо відносний ризик передчасної смерті не перевищуватиме одиницю на рівні значущості 5\% по усім областям

держави, то скорочення ВРПЖ лише через зовнішні причини відбудеться на 8,4\%, що в економічному еквіваленті складе 3-4 млрд. грн.

\section{Висновки}

1. Середньорічний обсяг втрачених років потенційного життя через усі причини смерті (АОOҮ99) серед населення України протягом 2015-2016 років становив 3098840 люд.-років, у тому числі за трьома основними класами причин смерті: 909848 люд.-років через хвороби системи кровообігу (100-199), 523139 люд.-років через новоутворення (C00-D48), 670169 люд.-років через зовнішні причини (V01-Y99).

2. Водночас як стандартизований показник смертності протягом 2012-2016 років має значну тенденцію до зростання, показник ВРПЖ демострує тенденцію до зменшення 3

Таблиця 3

Зовнішні причини смертності: інтервальні оцінки $\mathbf{R R}_{\mathrm{BP}}$ та рейтинг областей держави 2016 року

\begin{tabular}{|c|c|c|}
\hline Ранг & \multicolumn{2}{|c|}{ Зовнішні причини смертності } \\
\hline & Жінки, 95\%ДІ & Чоловіки, 95\%ДІ \\
\hline 1 & Кіровоградська $(1,45-1,53)$ & Житомирська $(1,38-1,41)$ \\
\hline 2 & Херсонська $(1,35-1,42)$ & Чернігівська $(1,35-1,38)$ \\
\hline 3 & Одеська, Миколаївська $(1,28-1,35)$ & Херсонська $(1,30-1,33)$ \\
\hline \multicolumn{3}{|c|}{$\ldots$} \\
\hline 23 & м. Київ, $(0,57-0,61)$ & Вінницька $(0,17-0,20)$ \\
\hline 22 & Тернопільська $(0,59-0,66)$ & м. Київ $(0,60-0,62)$ \\
\hline 21 & Івано-Франківська $(0,63-0,69)$ & Ів.-Франківська $(0,64-0,67)$ \\
\hline
\end{tabular}

Таблиця 4

Потенційна соціально-економічна вигода держави при скороченні передчасної смертності через зовнішні причини, 2016 р.

\begin{tabular}{|c|c|c|c|}
\hline $\begin{array}{c}\text { Потенційне скорочення передчасної } \\
\text { смертності, людино-роки }\end{array}$ & \multicolumn{2}{|c|}{$\begin{array}{r}\text { Потенційна вигода держави, } \\
\text { млн. грн. }\end{array}$} \\
\hline Точкова оцінка & $95 \%$ ДІ & Точкова оцінка & $95 \%$ ДІ \\
\hline 54055 & $48588-59521$ & 3783,85 & $3401,16-4166,47$ \\
\hline
\end{tabular}


локальним піком у 2014 році на рівні 49,38 \%о і 128,84 \%о відповідно для жіночого та чоловічого населення. Останнє зумовлене переважно збільшенням втрат через хвороби системи кровообігу та зовнішні причини смерті серед працездатного населення, можливо, також і через політичну ситуацію в Україні.

3. Результати ранжування областей держави за стандартизованим співвідношенням ВРПЖ свідчать, що найгірша ситуація за втратвми через передчасну смертність з усіх причин смерті склалася у Дніпропетровській та Житомирській областях, найліпша - у Вінницькій, Тернопільській та Івано-Франківській, де максимальне значення відносного ризику не перевищує 0,8 на 5\% рівні значущості.

4. Недоотримана річна вигода держави від передчасної смертності населення за усіма причинами смерті у грошовому вимірі становила 216919 млн. грн. (у середньому за 2015-2016 роки), при цьому внесок трьох основних причин смерті - це 68\%, хоча у класичній структурі смертності їхня питома вага становить 87\%. Це свідчить про те, що не приділяється належна увага передчасній смертності через такі причини, як інфекційні та паразитарні хвороби (А00-В99), хвороби органів дихання (J00-J99) та органів травлення (K00-K93), окремим станам, що виникають у перинатальному періоді (Р00-Р96), вродженим вадам розвитку, деформаціям та хромосомним аномаліям (Q00-Q99)

5. Оцінка стану громадського здоров'я при використанні ВРПЖ змінює пріоритетність проблем, сформованих на базі структури основних процесів відтворення населення: народжуваності та смертності. 3 одного боку, це дає додаткові аргументи для концентрації зусиль на зниження смертності саме серед населення працездатного віку, а з іншого - дозволяє оцінювати ефективність вжитих заходів зі скорочення смертності шляхом зіставлення витрат на відповідні програми та отримані результати у термінах економічної оцінки ВРПж.

\section{ЛІТЕРАТУРА}

1. Спицына Л.Ю.,

Спицын В.В. Оценка комплексной эффективности социально-экономического благополучия населения для целей государственного регулирования. Экономический анализ: теория и практика. 2015. № 16 (415).

C. 16-25.

2. Оприлюднення експресвипусків Держстату у 2018 році. URL : http://www.ukrstat. gov.ua/

3. Светый Л.И., Лопухова В.А., Тарасенко И.В., Климкин А.С. Применение системы оценки технологий здравоохранения в принятии эффективных управленческих решений. Здоровье и образование в XXI веке.

2013. № 1-4.

C. 234-235.

4. Gardner J.W., Sanborn J.S. Years of potential life lost (YPLL) - what does it measure?

Epidemiology. 1990. № 1 (4). P. 23-27.

5. Murray C.J.L., Lopez A.D. Global Burden of Disease:

A comprehensive assessment of mortality and disability from diseases, injuries, and risk factors in 1990 and projected to 2020 (The Global Burden of Disease and Injury). Geneva : WHO, 1996. URL : http://www.

who.int/iris/han-

dle/10665/41864.

6. Демографічний щорічник за 2017 рік. URL : http://www. ukrstat.gov.ua/druk/publicat/kat _u/2018/zb/11/zb_dy_2017.pdf

7. Карташова C.C.,

Щетініна О.К., Канєва Т.В. Вартість середньостатистичного життя в Україні: міжнародний досвід, рекомендації при використанні. Громадське здоров'я: проблеми та перспективи розвитку: зб. тез доп. наук.-практ. конф. Острог, 2018. С. 198-200.

8. Сердюк А.М.

Тимченко О.І., Карташова С.С Генофонд і здоров'я населення: Розвиток методології оцінки: монографія. Київ :

Медінформ, 2008. 183 с.

9. Карташова С.С., Тимченко О.И. Совершенствование методов оценки общественного здоровья: применение показателей стандартизованного и кумулятивного риска смерти. Гигиена и санитария, 2006. № 5. С. 83-86.

\section{REFERENCES}

1. Spitsyna L.Yu. and Spitsyn V.V. Ekonomicheskiy analiz: teoriya i praktika. 2015 ; 16 (415) : 16-25

(in Russian).

2. Opryliudnennia ekspresvypuskiv Derzhstatu u 2018 rotsi [Promulgation of the ExpressEditions of the Derzhstat in 2018]. URL : http://www.ukrstat.gov.ua/ (in Ukrainian)

3. Svetyi L.I., Lopukhova V.A. Tarasenko I.V. and Klimkin A.S. Zdorove i obrazovanie $v$ XXI veke. 2013 ; 1-4 : 234-235 (in Russian).

4. Gardner J.W. and Sanborn J.S. Epidemiology. $1990 ; 1(4): 23-27$.

5. Murray C.J.L. and Lopez A.D. Global Burden of Disease: A Comprehensive Assessment of Mortality and Disability from Diseases, Injuries, and Risk Factors in 1990 and Projected to 2020 (The Global Burden of Disease and Injury). Geneva : WHO; 1996. URL : http://www. who.int/iris/handle/10665/41864.

6. Demohrafichnyi shchorichnyk za 2017 rik [Demographic Year-Book for 2017]. URL : http://www.ukrstat.gov.ua/druk/ publicat/kat_u/2018/zb/11/zb_d y_2017.pdf (in Ukrainian).

7. Kartashova S.S., Shchetinina O.K. and Kaneva T.V. Vartist serednostatystychnoho zhyttia v Ukraini: mizhnarodnyi dosvid, rekomendatsii pry vykorystanni [Cost of the Average Life in Ukraine : International

Experience, Recommendations at the Application]. In :

Hromadske zdorovia: proplemy ta perspektyvy rozvytku: mater. konf. [Public Health: Problems and Prospects of the Development: Mater. Conf.] Ostroh, Ukraine ; 2018 : 198-200 (in Ukrainian).

8. Serdiuk A.M., Tymchenko O.I. and Kartashova S.S. Henofond i zdorovia naselennia: Rosvytok metodolohii otsinky: monohrafiia [Gene Pool and Health of Population:

Development of Assessment Methodology : Monograph]. Kyiv : Medinform ; 2008 : 183 p. (in Ukrainian).

9. Kartashova S.S. and Tymchenko O.I. Gigiena $i$ sanitaria. 2006 ; 5 ; 83-86 (in Russian).

Надійшла до редакції 05.03.2019 